\title{
Prioritas Pengembangan Usaha Mikro, Kecil dan Menengah (UMKM) Sektor Non-Unggulan Provinsi Jawa Tengah
}

\author{
Andryan Setyadharma ${ }^{1}$, Rahma Wijayanti ${ }^{2}$, Karmelia A.N. Fauzin ${ }^{2}$, \\ M. Lutfi Febryansyah ${ }^{2}$ \\ ${ }^{1}$ Dosen Fakultas Ekonomi, Universitas Negeri Semarang \\ ${ }^{2}$ Mahasiswa Fakultas Ekonomi, Universitas Negeri Semarang \\ Permalink/DOI: http://dx.doi.org/10.32830/jfres.v1i1.1034.g779
}

Received: June 2018; Accepted: August 2018; Published: September 2018

\begin{abstract}
Abstrak
Salah satu cara yang dilakukan untuk mengetahui potensi daerah adalah dengan melakukan perhitungan Location Quotient (LQ) untuk mengetahui sektor-sektor unggulan suatu daerah. Penelitian terdahulu telah menunjukkan bahwa saran kebijakan berkonsentrasi pada sektor-sektor unggulan yang meningkatkan perekonomian daerah dengan pembahasan sektor-sektor yang non-unggulan yang terbatas. Penelitian ini bertujuan untuk: (1) mengetahui apakah sektor-sektor unggulan memberikan trickle down effect (efek merembes ke bawah) bagi sektor-sektor non-unggulan lainnya melalui perhitungan LQ, (2) menentukan sektor dan sub sektor nonunggulan Usaha Mikro, Kecil dan Menengah (UMKM) yang perlu diproritaskan pengembangannya dikaitkan dengan Rencana Pembangunan Jangka Menengah Daerah (RPJMD) Provinsi Jawa Tengah. Hasil LQ untuk tahun 2010-2016 ditemukan bahwa dari 17 sektor ekonomi di Jawa Tengah selama periode tersebut hanya ada satu sektor yang sebelumnya adalah sektor non-unggulan menjadi sektor unggulan, yaitu sektor jasa pendidikan. Hasil LQ tersebut juga menunjukkan bahwa empat sektor selalu menjadi sektor unggulan dan delapan sektor selalu menjadi sektor non-unggulan, dua sektor sempat berubah posisi namun kembali seperti semula di tahun berikutnya dan dua sektor berubah dari sektor unggulan menjadi sektor non-unggulan. Pemerintah daerah perlu memperhatikan sektor-sektor non-unggulan UMKM dalam rangka meningkatkan perekonomian daerah.
\end{abstract}

Kata Kunci: Bank Jateng, UMKM, location quotient, sektor unggulan dan non-unggulan

\begin{abstract}
One way to find out regionals' potentials is by calculating location quotient $(L Q)$ in order to identify basic sectors of regions. Previous studies have shown that policy advices given were to pay attention on the basic sectors to improve the regional economy, with less discussion on non-basic sectors. The aims of this study are: (1) to access whether there are trickle down effects from basic to non basic sectors based on LQ calculation, (2) determine non basic and sub sectors of Micro, Small and Medium Enterprises (MSMEs) to be prioritized for development based on Central Java Province's Medium Term Development Planning. LQ calculations during 2010 to 2016 period show that from 17 economic sectors in Central Java, education services sector was the only sector that a non-basic sector in 2010 and became a basic sector in 2016. LQ results also show that four sectors have always been basic sectors and eight sectors have always been non-basic sectors, the two sectors had changed but returned as before in the next year and two sectors changed from basic sectors to non-basic sectors. This study suggests that Central Java government should pay attention to the non-basic sectors of MSMEs in order to improve the economy of Central Java.
\end{abstract}

Key Words : Bank Jateng, MSMEs, location quotient, basic and non-basic sectors

How to Cite: Setyadharma, A., Wijayanti, R., Fauzin, K.A.N., Febryansyah, M.L. (2018). Prioritas Pengembangan Usaha Mikro, Kecil dan Menengah (UMKM) Sektor Non-Unggulan Provinsi Jawa Tengah. JFRES: Journal of Fiscal and Regional Economy Studies, 1 (1), 109-118. doi: http://dx.doi.org/10.32830/jfres.v1i1.1034.g779 


\section{PENDAHULUAN}

Desentralisasi dan otonomi daerah telah memberikan kesempatan yang luas bagi pemerintah daerah untuk berkembang secara mandiri berdasarkan potensi-potensi yang dimilikinya untuk dapat meningkatkan pertumbuhan ekonomi daerahnya. Potensi-potensi ekonomi yang ada di daerah menjadi modal dasar yang penting untuk mendorong pertumbuhan ekonomi daerah, penyerapan tenaga kerja yang baru dan peningkatan investasi di daerah. Pertumbuhan ekonomi daerah menjadi salah satu tolak ukur keberhasilan pembangunan ekonomi daerah dan pemerintah daerah berkepentingan untuk meningkatkannya.

Salah satu potensi penting yang harus diberdayakan oleh pemerintah daerah untuk meningkatkan pertumbuhan ekomnomi daerah adalah Usaha Mikro, Kecil dan Menengah (UMKM). UMKM mempunyai peran penting dan strategis dalam pembangunan ekonomi nasional pada umumnya dan daerah pada khususnya. Selain berperan dalam pertumbuhan ekonomi dan penyerapan tenaga kerja, UMKM juga berperan dalam mendistribusikan hasil-hasil pembangunan. UMKM juga telah terbukti tidak terpengaruh terhadap krisis. Ketika krisis menerpa pada periode tahun 1997 - 1998, hanya UMKM yang mampu tetap berdiri kokoh (Bank Indonesia, 2015).

Perkembangan jumlah UMKM di Indonesia juga cukup menggembirakan, menurut data dari Kementerian Koperasi dan UKM, jumlah UMKM di Indonesia dari tahun ke tahun terus mengalami pertumbuhan. Pada tahun 2001 jumlah UMKM adalah sekitar 40 juta dan pada tahun 2015 menjadi 59 juta unit usaha (Gambar 1). Bukan hanya jumlah UMKM saja yang terus berkembang, namun UMKM juga berkontribusi banyak dalam penyerapan tenaga kerja. Pada tahun 2001, jumlah tenaga kerja yang terserap di sektor UMKM adalah hampir 75 juta orang dan terus meningkat sampai tahun 2013 sebesar 107,6 juta orang ${ }^{1}$. Hal ini tentunya akan

\footnotetext{
${ }^{1}$ Tidak menemukan data jumlah tenaga kerja UMKM yang terbaru untuk tingkat nasional. Data yang berasal dari BPS membagi UMKM menjadi dua, yaitu (1) usaha mikro dan usaha kecil dan (2) industri besar dan menengah, sehingga data khusus tenaga kerja UMKM tidak dapat diperoleh.
}

berdampak baik untuk mengurangi penggangguran di Indonesia.

Sementara itu, UMKM di Provinsi Jawa Tengah juga menunjukkan perkembangan yang signifikan. Dari jumlah UMKM sebesar 64 ribu pada tahun 2008 naik menjadi hampir dua kali lipat pada triwulan ke tiga tahun 2017 sebesar hanpir 124 ribu unit usaha (Dinas Koperasi dan UMKM Provinsi Jawa Tengah, 2017). Selain itu, jumlah tenaga kerja yang dapat diserap di sektor UMKM di Jawa Tengah dari tahun 2008 - 2016 juga terus mengalami pertumbuhan tiap tahunnya. Pada tahun 2008, jumlah tenaga kerja sebanyak 265 ribu orang dan meningkat menjadi 842 ribu orang pada triwulan ke tiga tahun 2017 (op cit, 2017).

Namun tidak dapat dipungkiri bahwa perhatian terhadap UMKM masih kecil yang salah satunya ditandai dengan masih kecilnya pangsa kredit perbankan untuk UMKM. Data dari Bank Indonesia menujukkan bahwa jumlah kredit yang diberikan perbankan kepada UMKM terus mengalami peningkatan yang cukup baik, yaitu naik 140\% selama periode 2013 sampai 2016, walaupun jumlah nominal penyaluran kredit yang diberikan masih terhitung lebih sedikit dibandingkan kredit non-UMKM. Pada tahun 2013, pangsa kredit UMKM dari total kredit perbankan hanya sebesar 18,9 \% dan meningkat sedikit menjadi 19,9\% pada tahun 2016. (Bank Indonesia, 2017).

Untuk itu, perlu digali potensi-potensi sektoral UMKM yang ada di Provinsi Jawa Tengah. Salah satunya dapat dilihat melalui PDRB Provinsi Jawa Tengah. Tabel 1 menunjukkan kontribusi 17 sektor terhadap PDRB (Harga Konstan) Jawa Tengah. Dapat dilihat bahwa tiga sektor utama yang memberikan kontribusi paling besar terhadap PDB Jawa Tengah adalah pertama sektor Industri Pengolahan, kedua sektor Perdagangan Besar dan Eceran serta ketiga sektor Pertanian, Kehutanan dan Perikanan. Pada tahun 2013 sektor Pertanian, Kehutanan dan Perikanan pernah berada di posisi ke dua namun pada tahun 2014 sampai tahun 2016 menempati posisi ketiga. Ketiga sektor ini menyumbangkan total $45 \%$ secara rata-rata dari keseluruhan PDRB Jawa Tengah. Bila dilihat dari kontribusi sektoralnya, apakah 


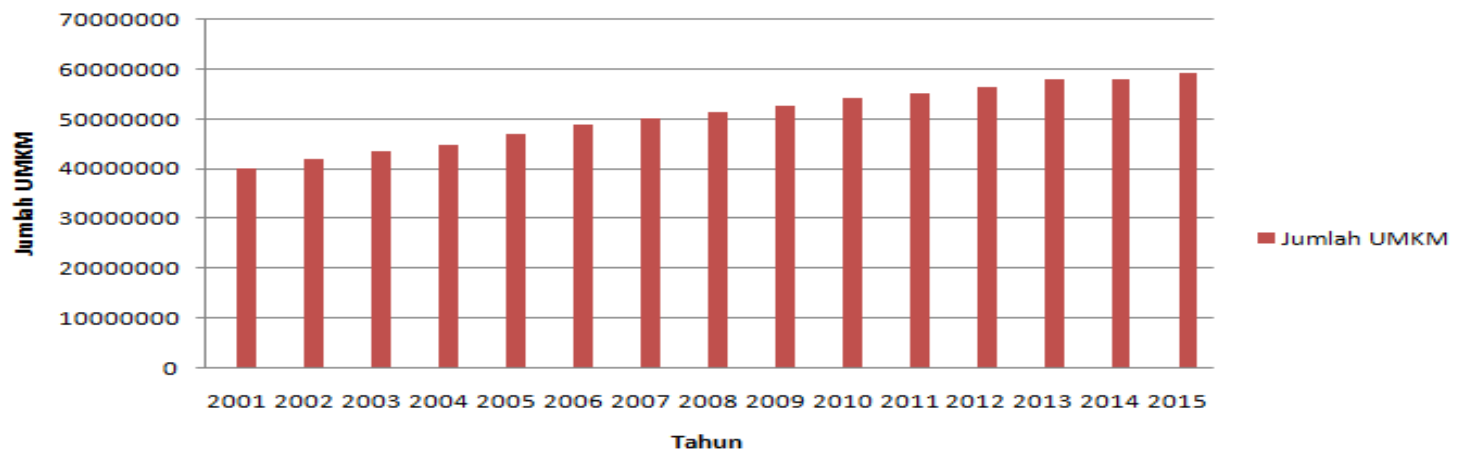

Sumber: Kementerian Koperasi dan UKM (2016)

Gambar 1. Jumlah UMKM di Indonesia Tahun 2001 - 2015

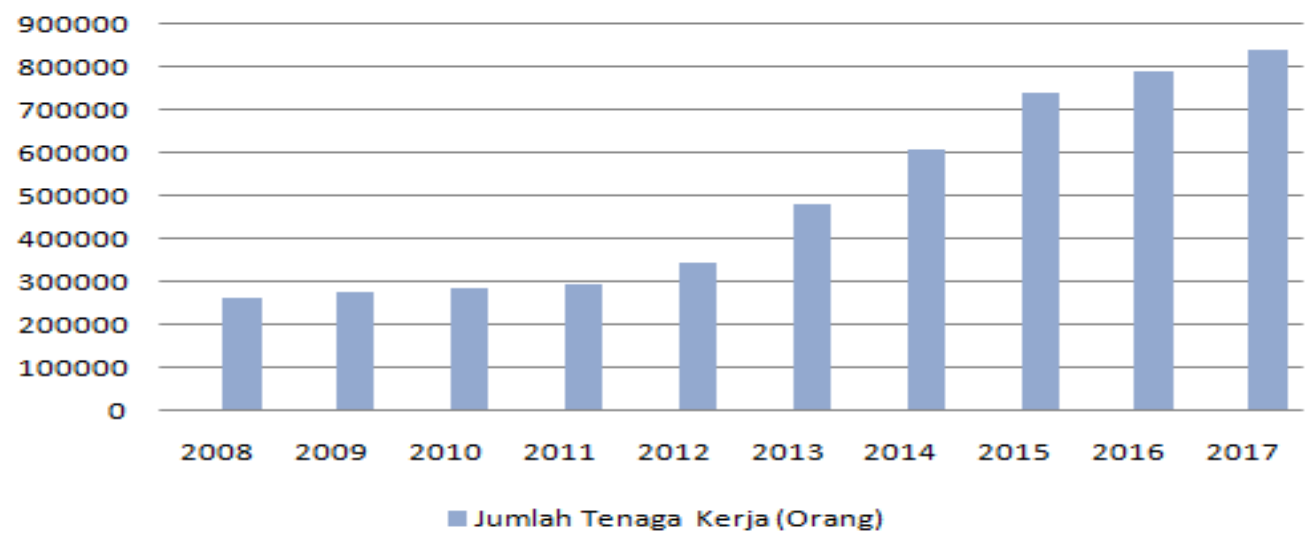

Sumber : Dinas Koperasi dan UMKM Provinsi Jawa Tengah, 2017

Gambar 2. Tenaga Kerja UMKM di Jawa Tengah Tahun 2008 - 2017

dapat dipastikan bahwa sektor-sektor yang merupakan penyumbang terbesar bagi PDRB provinsi Jawa Tengah merupakan sektor unggulan di Jawa Tengah dan apakah keberadaan sektor unggulan mampu memberikan dampak bagi sektor non-unggulan yang lainnya?

Menurut Suyatno (2000), sektor unggulan merupakan sektor yang dianggap bisa bersaing dengan sektor yang sama di tenpat lain, baik itu dalam skala nasional maupun domestik. Untuk mengetahui sektor unggulan biasanya dilakukan pembandingan dalam lingkup wilayah yang berbeda. Sektor unggulan pada suatu daerah dapat dilihat dari kemampuan memenangkan persaingan pada sektor yang sama di daerah lain. Menurut Mawardi (1997), sektor unggulan selain mampu menghasilkan nilai tambah pada proses produksi, juga mampu menghasilkan multiplier effect terhadap pertumbuhan di sektor lain, serta memiliki permintaan yang tinggi baik itu di pasar domestik maupun internasional. Sektor unggulan pada suatu daerah akan memiliki potensi yang lebih besar untuk tumbuh lebih cepat dibandingkan dengan sektor lainnya, apalagi dengan adanya tambahan dukungan berupa akumulasi modal, penyerapan tenaga kerja yang terus tumbuh, dan juga kemajuan teknologi (technological progress). Sektor unggulan suatu daerah juga dapat dimanfaatkan untuk menciptakan peluang investasi (Rachbini, 2001).

Sutrisno (2011) berpendapat bahwa upaya yang dapat dilakukan untuk meningkatkan perekonomian suatu daerah salah satunya adalah dengan menganalisis dan menggali sektor-sektor yang memiliki keunggulan komparatif maupun memiliki keunggulan kompetitif. Keunggulan komparatif merupakan keunggulan suatu sektor untuk kebutuhan domestik dan selebihnya mampu diekspor ke daerah lain. Sedangkan keunggulan kompetitif merupakan keunggulan yang di miliki suatu sektor ekonomi untuk bersaing atau memiliki daya saing di pasar. 
Tabel 1. Kontribusi Sektoral Terhadap PDRB Jawa Tengah tahun 2013 - 2016

\begin{tabular}{lrrrr}
\hline \multicolumn{1}{c}{ PDB Lapangan Usaha } & $\mathbf{2 0 1 3}$ & $\mathbf{2 0 1 4}$ & $\mathbf{2 0 1 5}$ & $\mathbf{2 0 1 6}$ \\
\hline Pertanian, Kehutanan, dan Perikanan & $13.4 \%$ & $13.2 \%$ & $13.0 \%$ & $12.8 \%$ \\
Pertambangan dan Penggalian & $11.0 \%$ & $9.3 \%$ & $8.5 \%$ & $8.2 \%$ \\
Industri Pengolahan & $21.0 \%$ & $21.6 \%$ & $21.5 \%$ & $21.4 \%$ \\
Pengadaan Listrik dan Gas & $1.0 \%$ & $1.1 \%$ & $1.1 \%$ & $1.1 \%$ \\
Pengadaan Air, Pengelolaan Sampah, Limbah dan Daur Ulang & $0.1 \%$ & $0.1 \%$ & $0.1 \%$ & $0.1 \%$ \\
Konstruksi & $9.5 \%$ & $9.7 \%$ & $9.8 \%$ & $9.8 \%$ \\
Perdagangan Besar dan Eceran; Reparasi Mobil dan Sepeda Motor & $13.2 \%$ & $13.7 \%$ & $13.4 \%$ & $13.3 \%$ \\
Transportasi dan Pergudangan & $3.9 \%$ & $3.8 \%$ & $3.9 \%$ & $4.0 \%$ \\
Penyediaan Akomodasi dan Makan Minum & $3.0 \%$ & $3.0 \%$ & $3.0 \%$ & $3.0 \%$ \\
Informasi dan Komunikasi & $3.6 \%$ & $4.5 \%$ & $4.7 \%$ & $4.9 \%$ \\
Jasa Keuangan dan Asuransi & $3.9 \%$ & $3.7 \%$ & $3.9 \%$ & $4.0 \%$ \\
Real Estate & $2.8 \%$ & $3.0 \%$ & $3.0 \%$ & $3.0 \%$ \\
Jasa Perusahaan & $1.5 \%$ & $1.6 \%$ & $1.7 \%$ & $1.7 \%$ \\
Administrasi Pemerintahan, Pertahanan dan Jaminan Sosial Wajib & $3.9 \%$ & $3.5 \%$ & $3.5 \%$ & $3.4 \%$ \\
Jasa Pendidikan & $3.2 \%$ & $3.1 \%$ & $3.2 \%$ & $3.1 \%$ \\
Jasa Kesehatan dan Kegiatan Sosial & $1.0 \%$ & $1.1 \%$ & $1.1 \%$ & $1.1 \%$ \\
Jasa lainnya & $1.5 \%$ & $1.6 \%$ & $1.6 \%$ & $1.7 \%$ \\
\hline
\end{tabular}

Sumber: BPS Provinsi Jawa Tengah, 2017

Banyak penelitian sebelumnya di Indonesia yang membahas tentang sektor unggulan. Misalnya, Ryantika dan Utama (2017), dalam penelitiannya di Kabupaten Gianyar menjelaskan pentingnya mengetahui potensi wilayah yang dapat digunakan untuk mengembangkan pembangunan daerah secara efektif dan efisien. Sektor yang menjadi prioritas pembangunan wilayah yang dikembangkan adalah sektor dengan prioritas pertama (utama), sedangkan untuk sektor lainnya juga harus dikembangkan untuk mempertahankan dan mengembangkan keberadaannya.

Cahyani (2016) menyatakan bahwa untuk meningkatkan PDRB suatu daerah pemerintah harusnya lebih mengutamakan pengembangan sektor dan subsektor potensial yang menjadi sektor basis dengan tidak mengabaikan sektor dan sub sektor lain dalam perencanaan dan pelaksanaan pembangunan. Penelitian ini menunjukkan bahwa sektor pertanian merupakan sektor yang sangat potensial untuk dikembangkan, karena terdapat 17 kecamatan di Kabupaten Wonogiri di mana sektor pertaniannya menjadi sektor basis. Strategi utama yang dapat diambil untuk mengembangkan potensi ekonomi kecamatan di Kabupaten Wonogiri yang mayoritas penduduknya bermata pencaharian petani adalah dengan asuransi pertanian yang ditujukan untung melindungi petani dari kerugian karena gagal panen, peningkatan program pemberdayaan masyarakat, meningkatkan pengelolaan sektor potensial dan peningkatan sarana dan prasarana terutama transportasi, komunikasi dan industri.

Sementara itu, Ariyanto (2013) mengemukakan, dalam menentukan skala prioritas diperlukan dalam menentukan sektor-sektor pembangunan. Sektor yang dipilih adalah sektor yang mampu menjadi lokomotif perkembangan sektor lainnya, baik di sektor hulu (backword effect) maupun ke sektor hilir (foreward effect). Sehingga sektor yang dipilih mampu memberikan multiplier effect yang besar terhadap perekonomian daerah (sektor unggulan).

Dari beberapa penelitian sebelumnya, dapat disimpulkan bahwa saran yang diberikan dalam upaya meningkatkan perekonomian suatu daerah adalah melalui pemberdayaan sektor-sektor yang unggul yang dianggap: (1)mampu menjadi lokomotif perkembangan sektor lainnya; (2) mampu memberikan multiplier effect yang besar terhadap perekonomian daerah; (3) mampu memberikan nilai tambah yang besar pada proses produksi; dan (4) menimbulkan multiplier effect terhadap pertumbuhan perekonomian di sektor lain. 
Sejauh pengetahuan penulis, belum pernah ada penelitian yang menunjukkan bahwa sektor unggulan akan memberikan dampak langsung maupun tidak langsung pada sektor nonunggulan. Oleh karena itu, tujuan dari penelitian ini adalah: (1) mengetahui apakah sektor-sektor unggulan memberikan trickledown effect (efek merembes ke bawah) bagi sektor-sektor nonunggulan lainnya. Logikanya adalah, jika ada dampak dari sektor unggulan terhadap sektor non-unggulan maka paling tidak ada sektor nonunggulan akan menjadi sektor unggulan, dan (2) menentukan sektor dan sub sektor non-unggulan Usaha Mikro, Kecil dan Menengah (UMKM) yang perlu diproritaskan pengembangannya dikaitkan dengan Rencana Pembangunan Jangka Menengah Daerah (RPJMD) Provinsi Jawa Tengah. Berdasarkan RPJMD Provinsi Jawa Tengah Tahun 2013-2018, industri diarahkan pada produk-produk unggulan berbasis industri kerajinan sehingga perlu ditentukan mana saja sektor non-unggulan UMKM yang dapat dikembangkan berdasarkan RPJMD Jawa Tengah.

\section{METODE PENELITIAN}

Penelitian ini menggunakan data sekunder, data sekunder adalah data yang telah tersedia dan telah diproses oleh suatu pihak sebagai hasil atas penelitian yang telah dilaksanakan. Data sekunder dalam penelitian ini berupa data time series selama enam tahun, adapun data yang digunakan adalah data yang diambil dari website Badan Pusat Statistik Jawa Tengah mengenai PDRB Jawa Tengah Menurut Lapangan Usaha Atas Dasar Harga Konstan 2010 periode tahun 2010 2016 dan juga PDB Menurut Lapangan Usaha Atas Dasar Harga Konstan 2010 periode tahun 2010 - 2016 yang berasal dari website Badan Pusat Statistik.

Alat analisis yang digunakan adalah Location Quotient (LQ), Analisis LQ adalah suatu alat analisis yang digunakan untuk menunjukkan basis ekonomi, potensi dan pemusatan perekonomian di suatu wilayah.Alat analisis ini juga dipakai untuk mengukur konsentrasi dari suatu kegiatan (industri) serta perannya dalam pembangunan perekonomian baik itu regional maupun nasional.

Rumus menghitung LQ adalah sebagai berikut:

$$
\mathrm{LQ}=(S \mathfrak{i} / S) /(N i / N)
$$

Keterangan :

LQ = Location Quotient sektor $i$ wilayah Jawa Tengah

$\mathrm{Si}$ = pendapatan sektor $i$ di wilayah Jawa Tengah

$\mathrm{Ni}=$ Pendapatan sektor i di Indonesia

$\mathrm{S}$ = pendapatan total di wilayah Jawa Tengah

$\mathrm{N}=$ pendapatan total di Indonesia

\section{Kriteria:}

a) LQ > 1 : unggulan, sektor tersebut produksinya mencukupi kebutuhan wilayahnya dan ekpor ke daerah lain.

b) LQ $<1$ : bukan unggulan,sektor tersebut tidak mencukupi daerahnya untuk itu dibutuhkan bantuan di wilayah lain.

c) $\mathrm{LQ}=1$ sektor hanya dapat memenuhi kebutuhan daerahnya sendiri tetapi tidak dapat melakukan ekspor ke daerah lain maupun impor ke daerah lain

\section{HASIL DAN PEMBAHASAN}

Hasil perhitungan location quotient (LQ) selama periode tahun 2010 sampai tahun 2016 menggunakan data nilai PDRB Berdasarkan Lapangan Usaha dengan harga konstan 2010 pada Tabel 2 menunjukkan ada empat sektor yang selalu menjadi kategori sektor unggulan selama periode 2010 sampai 2016, yaitu: (1)Pertanian, Kehutanan, dan Perikanan; (2) Industri Pengolahan; (3) Perdagangan Besar dan Eceran; Reparasi Mobil dan Sepeda Motor; dan (4) Konstruksi. Ketiga sektor pertama yang menjadi sektor unggulan versi perhitungan LQ merupakan sektor-sektor yang memberikan kontribusi paling besar pada PDRB Jawa Tengah (lihat kembali tabel 1). Sedangkan sektor unggulan keempat, yaitu Konstruksi merupakan penyumbang terbesar nomor lima setelah sektor Pertambangan dan Penggalian di nomor Empat. 
Tabel 2. Hasil Perhitungan Location Quotient Berdasarkan Lapangan Usaha di Provinsi Jawa Tengah Berdasarkan Nilai PDRB dengan Harga Konstan 2010 (2010 - 2016)

\begin{tabular}{lccccccr}
\hline \multicolumn{1}{c}{ Lapangan Usaha } & $\mathbf{2 0 1 0}$ & $\mathbf{2 0 1 1}$ & $\mathbf{2 0 1 2}$ & $\mathbf{2 0 1 3}$ & $\mathbf{2 0 1 4}$ & $\mathbf{2 0 1 5}$ & 2016** \\
\hline Pertanian, Kehutanan, dan Perikanan & 1.15 & 1.17 & 1.15 & 1.12 & 1.07 & 1.08 & 1.07 \\
Pertambangan dan Penggalian & 0.20 & 0.17 & 0.17 & 0.18 & 0.22 & 0.23 & 0.27 \\
Industri Pengolahan & 1.57 & 1.58 & 1.63 & 1.67 & 1.64 & 1.64 & 1.63 \\
Pengadaan Listrik dan Gas & 0.10 & 0.09 & 0.10 & 0.11 & 0.10 & 0.10 & 0.11 \\
Pengadaan Air, Pengelolaan Sampah, & 1.02 & 1.07 & 1.03 & 1.00 & 0.92 & 0.87 & 0.86 \\
Limbah dan Daur Ulang & 1.13 & 1.10 & 1.08 & 1.07 & 1.04 & 1.03 & 1.04 \\
Konstruksi & & & & & & & \\
Perdagangan Besar dan Eceran; & 1.09 & 1.11 & 1.11 & 1.10 & 1.05 & 1.06 & 1.07 \\
Reparasi Mobil dan Sepeda Motor & 0.84 & 0.84 & 0.83 & 0.80 & 0.85 & 0.86 & 0.85 \\
Transportasi dan Pergudangan & & & & & & & \\
Penyediaan Akomodasi dan Makan & 1.03 & 1.05 & 1.03 & 0.99 & 1.02 & 1.04 & 1.05 \\
Minum & 0.90 & 0.95 & 0.99 & 1.03 & 0.88 & 0.87 & 0.86 \\
Informasi dan Komunikasi & 0.79 & 0.79 & 0.72 & 0.69 & 0.70 & 0.70 & 0.70 \\
Jasa Keuangan dan Asuransi & 0.59 & 0.62 & 0.63 & 0.64 & 0.60 & 0.62 & 0.63 \\
Real Estate & 0.20 & 0.20 & 0.20 & 0.21 & 0.21 & 0.21 & 0.21 \\
Jasa Perusahaan & 0.84 & 0.79 & 0.75 & 0.74 & 0.80 & 0.80 & 0.79 \\
Administrasi Pemerintahan, & & & & & \\
Pertahanan dan Jaminan Sosial Wajib & 0.89 & 0.99 & 1.05 & 1.06 & 1.16 & 1.15 & 1.19 \\
Jasa Pendidikan & 0.68 & 0.70 & 0.72 & 0.72 & 0.73 & 0.72 & 0.75 \\
Jasa Kesehatan dan Kegiatan Sosial & 1.06 & 1.05 & 1.02 & 1.03 & 0.99 & 0.95 & 0.95 \\
Jasa lainnya & & & & & & & \\
\hline
\end{tabular}

Sumber: data diolah

Catatan :

* Nilai PDRB yang digunakan tahun 2015 adalah angka sementara

** Nilai PDRB yang digunakan tahun 2016 adalah angka amat sementara

Sementara itu, ada delapan sektor yang tidak pernah menjadi kategori sektor unggulan selama periode 2010 sampai 2016, yaitu: (1) Pertambangan dan Penggalian; (2) Pengadaan Listrik dan Gas; (3)Transportasi dan Pergudangan; (4)Jasa Keuangan dan Asuransi; (5) Real Estate; (6) Jasa Perusahaan; (7) Administrasi Pemerintahan, Pertahanan dan Jaminan Sosial Wajib; dan (8) Jasa Kesehatan dan Kegiatan Sosial. Sektor-sektor ini memiliki nilai LQ yang lebih rendah dari 1. Menarik untuk dilihat bahwa sektor Pertambangan dan Penggalian bukan merupakan sektor unggulan padahal sektor ini merupakan penyumbang terbesar keempat pembentukan PDRB Provinsi Jawa Tengah.

Ada satu sektor yang sempat menjadi sektor unggulan pada tahun 2013 namun kembali menjadi sektor non-unggulan pada tahun selanjutnya, yaitu sektor Informasi dan Komunikasi. Kebalikannya, ada satu sektor, yaitu sektor Penyediaan Akomodasi dan Makan
Minum, yang pernah menjadi sektor nonunggulan pada tahun 2013 namun kembali menjadi sektor unggulan pada tahun berikutnya. Dapat dilihat juga bahwa ada dua sektor usaha yang sempat menjadi sektor unggulan yang kemudian menjadi sektor non-unggulan (Sektor Pengadaan Air, Pengelolaan Sampah, Limbah dan Daur Ulang dan Sektor Jasa lainnya). Tabel 1 juga menunjukkan bahwa dari 17 sektor ekonomi di Jawa Tengah selama periode tersebut hanya ada satu sektor yang sebelumnya adalah sektor non-unggulan menjadi sektor unggulan, yaitu sektor jasa pendidikan.

Ada dua hal menarik dari hasil perhitungan LQ. Pertama terdapat dua sektor yang sebelumnya pernah menjadi sektor unggulan kemudian turun status menjadi sektor non-unggulan. Hal ini menunjukkan ada kesalahan pengelolaan sektor unggulan di Jawa Tengah. Dengan adanya hasil tersebut, dapat dilihat bahwa status sebagai sektor unggulan tidak dapat selamanya 
dipertahankan sehingga sangat sulit mengandalkan sektor unggulan menjadi lokomotif bagi sektor non-unggulan lain sementara sektor itu sendiri tidak bisa mempertahankan statusnya sebagai sektor unggulan. Kedua, terdapat delapan sektor yang selama periode penelitian (2010 - 2016) tidak pernah menjadi sektor unggulan dan hanya satu sektor yang akhirnya bisa menjadi sektor unggulan. Hal ini dapat menjadi suatu indikasi bahwa sektor unggulan hanya sedikit memberikan dampak terhadap perkembangan sektor lain. Dari dua poin di atas, dapat disimpulkan bahwa untuk mengembangkan sektor-sektor non-unggulan tidak boleh hanya mengandalkan dampak yang diberikan oleh sektor unggulan. Dengan demikian,fokus seharusnya diarahkan pada bagaimana meningkatkan sektor non-unggulan melalui pemberdayaan UMKM dalam rangka meningkatkan perekonomian daerah yang tidak hanya bertumpu pada sektor unggulan. Sehingga harapannya kedepan bukan hanya sektor unggulan saja yang terus dikembangkan namun sektor sektor nonunggulan juga memiliki peran dalam mewujudkan pertumbuhan ekonomi Jawa Tengah.

Selanjutnya, dilakukan perhitungan LQ sampai pada tingkatan subsektor dan sub subsektor lapangan usaha dan menentukan subsektor dan sub subsektor non-unggulan. Yang menarik dari hasil LQ di Tabel 3 adalah ketika melihat pada hasil LQ subsektor dan sub subsektor. Dapat disimpulkan bahwa ketika suatu sektor dinyatakan sebagai sektor unggulan, belum tentu sub sektor dan sub subsektornya juga sebagai sektor unggulan berdasarkan perhitungan LQ. Sebagai contoh, sektor Pertanian, Kehutanan, dan Perikanan adalah sektor unggulan namun subsektor Kehutanan dan Penebangan Kayu serta subsektor Perikanan bukanlah sektor unggulan. Sebaliknya, sektor Pertambangan dan Penggalian bukanlah sektor unggulan menurut perhitungan LQ.Namun subsektor Pertambangan dan Penggalian lainnya adalah subsektor unggulan. Dengan demikian, dimungkinkan suatu sektor menjadi sektor unggulan bukan karena didukung oleh seluruh subsektornya, namun dapat didukung oleh sebagian subsektornya saja. Oleh karena itu, cara yang dapat dilakukan adalah dengan meningkatkan nilai PDRB subsektor maupun sub seksektor tertentu.

UMKM dari subsektor dan sub subsektor mana yang sebaiknya didukung penuh oleh Bank Jateng? Salah satu caranya adalah mengkaitkannya dengan Rencana Pembangunan Jangka Menengah Daerah (RPJMD) Provinsi Jawa Tengah. Berdasarkan RPJMD Provinsi Jawa Tengah Tahun 2013-2018, industri diarahkan pada produk-produk unggulan berbasis industri kerajinan (lihat RPJMD Jawa TengahTahun 2013-2018 halaman II-7). Dari perhitungan LQ, yang terkait dengan industri kerajinan dengan LQ di bawah satu adalah: (1) Industri Kulit, Barang dari Kulit dan Alas Kaki; (2) Industri Karet, Barang dari Karet dan Plastik; (3) Industri Logam Dasar; dan (4) Industri Furnitur. Walaupun secara keseluruhan sektor Industri Pengolahan memiliki nilai LQ yang sudah lebih dari satu namun peningkatan sub subsektor masih diperlukan untuk kebaikan UMKM di sub sektor tersebut dan diharapkan mampu mendorong pertumbuhan ekonomi daerah.

RPJMD Provinsi Jawa Tengah Tahun 2013-2018 tidak membahas tentang Jasa Keuangan dan Asuransi. Jasa keuangan dan asuransi merupakan salah satu sektor yang masih menjadi sektor nonunggulan di Jawa Tengah. Mengingat pentingnya jasa keuangan dan asuransi bagi perekonomian di suatu daerah maka diperlukan pengembangan lebih lanjut pada sektor ini, khususnya dukungan pada UMKM subsektor asuransi dan dana pensiun yang memiliki LQ kurang dari satu. Usaha Mikro Kecil dan Menengah (UMKM) juga menghadapi berbagai risiko yang terkadang bisa membahayakan keberlanjutannya. Upaya proteksi terhadap UMKM tentunya sangat diperlukan, asuransi dapat menjadi salah satu upaya proteksi yang dapat diambil oleh pelaku UMKM untuk lebih kuat menghadapi segala rintangan. Namun saat ini masih banyak pelaku UMKM yang belum menganggap asuransi sebagai hal yang penting dan seringkali hanya fokus mengejar pertumbuhan pada masa awal berdirinya. Padahal, proteksi asuransi mampu membuat bisnis bekerja secara baik dan sehat hal ini dikarenakan asuransi akan membatu mengatasi risikorisiko buruk yang rawan dihadapi oleh UMKM. 
Peran Pemerintah Daerah Jawa Tengah diperlukan dalam proses pengembangan sektor UMKM di bidang asuransi di Jawa Tengah mengingat jasa asuransi dapat mendukung UMKM-UMKM lainnya yang nantinya akan mengembangkan perekonomian daerah.

Terakhir, Pemerintah Daerah Jawa Tengah diharapkan mendorong tumbuhnya UMKM sektor real estate. Seperti dilihat dari perhitungan LQ, sektor ini mempunyai nilai di bawah satu. UMKM di sektor ini mempunyai potensi untuk penyerapan tenaga kerja yang besar sehingga diharapkan mampu mengurangi pengangguran sehingga banyak orang yang memiliki penghasilan dan mampu menggerakkan ekonomi daerah lewat konsumsi yang lebih besar.

Tabel 3. Hasil Perhitungan Location Quotient Sektor, Subsektor dan Sub Subsektor Berdasarkan Lapangan Usaha di Provinsi Jawa Tengah Berdasarkan nilai PDRB dengan Harga Konstan $2010(2010-2016)$

\begin{tabular}{|c|c|c|c|c|c|c|c|c|}
\hline & Lapangan Usaha & 2010 & 2011 & 2012 & 2013 & 2014 & 2015* & $2016 * *$ \\
\hline Pert & anian, Kehutanan, dan Perikanan & 1.15 & 1.17 & 1.15 & 1.12 & 1.07 & 1.08 & 1.07 \\
\hline & Pertanian, Peternakan, Perburuan dan Jasa & & & & & & & \\
\hline & Pertanian & 1.14 & 1.14 & 1.15 & 1.15 & 1.15 & 1.16 & 1.16 \\
\hline & a. Tanaman Pangan & 1.48 & 1.41 & 1.42 & 1.42 & 1.42 & 1.48 & 1.47 \\
\hline & b. Tanaman Hortikultura & 2.11 & 2.26 & 2.26 & 2.23 & 2.30 & 2.27 & 2.26 \\
\hline & c. Tanaman Perkebunan & 0.31 & 0.32 & 0.33 & 0.34 & 0.34 & 0.34 & 0.34 \\
\hline & d. Peternakan & 1.38 & 1.44 & 1.43 & 1.44 & 1.53 & 1.52 & 1.56 \\
\hline & e. Jasa Pertanian dan Perburuan & 1.16 & 1.19 & 1.28 & 1.38 & 1.42 & 1.41 & 1.39 \\
\hline 2 & Kehutanan dan Penebangan Kayu & 0.66 & 0.68 & 0.67 & 0.69 & 0.72 & 0.68 & 0.67 \\
\hline & Perikanan & 0.42 & 0.41 & 0.40 & 0.41 & 0.41 & 0.39 & 0.39 \\
\hline Pert & ambangan dan Penggalian & 0.20 & 0.17 & 0.17 & 0.18 & 0.22 & 0.23 & 0.27 \\
\hline & Pertambangan Minyak, Gas dan Panas Bumi & 0.20 & 0.21 & 0.20 & 0.21 & 0.26 & 0.28 & 0.15 \\
\hline 2 & Pertambangan Batubara dan Lignit & 0.00 & 0.00 & 0.00 & 0.00 & 0.00 & 0.00 & 0.00 \\
\hline 3 & Pertambangan Bijih Logam & 0.42 & 0.01 & 0.003 & 0.00 & 0.00 & 0.00 & 0.00 \\
\hline & Pertambangan dan Penggalian Lainnya & 5.41 & 6.73 & 6.61 & 6.29 & 5.18 & 4.89 & 1.12 \\
\hline Ind & ustri Pengolahan & 1.57 & 1.58 & 1.63 & 1.67 & 1.64 & 1.64 & 1.63 \\
\hline 1 & Industri Batubara dan Pengilangan Migas & 1.37 & 1.24 & 1.20 & 1.16 & 1.48 & 1.58 & 1.61 \\
\hline & Industri Pengolahan Non Migas & 0.93 & 0.95 & 0.96 & 0.97 & 0.94 & 0.93 & 0.93 \\
\hline 1 & Industri Makanan dan Minuman & 1.19 & 1.25 & 1.20 & 1.25 & 1.16 & 1.18 & 1.15 \\
\hline 2 & Industri Pengolahan Tembakau & 5.17 & 5.05 & 5.16 & 5.10 & 5.01 & 4.77 & 4.75 \\
\hline 3 & Industri Tekstil dan Pakaian Jadi & 1.20 & 1.20 & 1.30 & 1.38 & 1.38 & 1.43 & 1.47 \\
\hline 4 & Industri Kulit, Barang dari Kulit dan Alas Kaki & 0.61 & 0.62 & 0.69 & 0.68 & 0.73 & 0.74 & 0.72 \\
\hline 5 & $\begin{array}{l}\text { Industri Kayu, Barang dari Kayu dan Gabus dan } \\
\text { Barang Anyaman dari Bambu, Rotan dan }\end{array}$ & & & & & & & \\
\hline & Sejenisnya & 1.41 & 1.45 & 1.45 & 1.50 & 1.48 & 1.53 & 1.64 \\
\hline 6 & Industri Kertas dan Barang dari Kertas; & & & & & & & \\
\hline & Percetakan dan Reproduksi Media Rekaman & 0.24 & 0.24 & 0.24 & 0.24 & 0.23 & 0.24 & 0.24 \\
\hline 7 & Industri Kimia, Farmasi dan Obat Tradisional & 0.62 & 0.70 & 0.74 & 0.76 & 0.72 & 0.69 & 0.68 \\
\hline 8 & Industri Karet, Barang dari Karet dan Plastik & 0.31 & 0.32 & 0.34 & 0.37 & 0.35 & 0.31 & 0.36 \\
\hline 9 & Industri Barang Galian bukan Logam & 0.57 & 0.61 & 0.61 & 0.61 & 0.59 & 0.56 & 0.56 \\
\hline 10 & Industri Logam Dasar & 0.26 & 0.27 & 0.28 & 0.28 & 0.28 & 0.26 & 0.26 \\
\hline 11 & Industri Barang Logam; Komputer, Bara & & & & & & & \\
\hline & Elektronik, Optik; dan Peralatan Listrik & 0.17 & 0.18 & 0.17 & 0.18 & 0.17 & 0.15 & 0.14 \\
\hline 12 & Industri Mesin dan Perlengkapan & 0.22 & 0.26 & 0.27 & 0.27 & 0.23 & 0.22 & 0.22 \\
\hline 13 & Industri Alat Angkutan & 0.08 & 0.07 & 0.07 & 0.08 & 0.08 & 0.08 & 0.08 \\
\hline 14 & Industri Furnitur & 0.79 & 0.88 & 0.82 & 0.85 & 0.84 & 0.85 & 0.87 \\
\hline
\end{tabular}




\begin{tabular}{|c|c|c|c|c|c|c|c|}
\hline Lapangan Usaha & 2010 & 2011 & 2012 & 2013 & 2014 & $2015 *$ & $2016^{* *}$ \\
\hline $\begin{array}{l}15 \text { Industri Pengolahan Lainnya; Jasa Reparasi dan } \\
\text { Pemasangan Mesin dan Peralatan }\end{array}$ & 0.41 & 0.45 & 0.46 & 0.46 & 0.42 & 0.41 & 0.45 \\
\hline Pengadaan Listrik dan Gas & 0.10 & 0.09 & 0.10 & 0.11 & 0.10 & 0.10 & 0.11 \\
\hline 1 Ketenagalistrikan & 1.20 & 1.23 & 1.27 & 1.29 & 1.15 & 1.13 & 1.13 \\
\hline 2 Pengadaan Gas dan Produksi Es & 0.14 & 0.13 & 0.11 & 0.11 & 0.17 & 0.19 & 0.18 \\
\hline $\begin{array}{l}\text { Pengadaan Air, Pengelolaan Sampah, Limbah dan } \\
\text { Daur Ulang }\end{array}$ & 1.02 & 1.07 & 1.03 & 1.00 & 0.92 & 0.87 & 0.86 \\
\hline Konstruksi & 1.13 & 1.10 & 1.08 & 1.07 & 1.04 & 1.03 & 1.04 \\
\hline $\begin{array}{l}\text { Perdagangan Besar dan Eceran; Reparasi Mobil dan } \\
\text { Sepeda Motor } \\
1 \text { Perdagangan Mobil, Sepeda Motor dan }\end{array}$ & 1.09 & 1.11 & 1.11 & 1.10 & 1.05 & 1.06 & 1.07 \\
\hline $\begin{array}{ll}1 & \text { Perdagangan Mobil, Sepeda Motor dan } \\
& \text { Reparasinya } \\
2 & \text { Perdagangan Besar dan Eceran, Bukan Mobil dan }\end{array}$ & 1.05 & 0.99 & 1.00 & 1.01 & 1.06 & 1.09 & 1.08 \\
\hline Sepeda Motor & 0.99 & 1.00 & 1.00 & 1.00 & 0.99 & 0.98 & 0.98 \\
\hline Transportasi dan Pergudangan & 0.84 & 0.84 & 0.83 & 0.80 & 0.85 & 0.86 & 0.85 \\
\hline 1 Angkutan Rel & 1.43 & 1.45 & 1.22 & 1.27 & 1.54 & 1.71 & 1.84 \\
\hline 2 Angkutan Darat & 1.52 & 1.57 & 1.65 & 1.65 & 1.51 & 1.51 & 1.51 \\
\hline Angkutan Laut & 0.87 & 0.88 & 0.94 & 1.04 & 0.94 & 0.90 & 0.96 \\
\hline Angkutan Sungai Danau dan Penyeberangan & 0.10 & 0.10 & 0.10 & 0.10 & 0.09 & 0.09 & 0.10 \\
\hline Angkutan Udara & 0.22 & 0.22 & 0.19 & 0.18 & 0.23 & 0.22 & 0.21 \\
\hline $\begin{array}{l}6 \text { Pergudangan dan Jasa Penunjang Angkutan; Pos } \\
\text { dan Kurir }\end{array}$ & 0.18 & 0.18 & 0.18 & 0.18 & 0.19 & 0.20 & 0.20 \\
\hline Penyediaan Akomodasi dan Makan Minum & 1.03 & 1.05 & 1.03 & 0.99 & 1.02 & 1.04 & 1.05 \\
\hline 1 Penyediaan Akomodasi & 0.72 & 0.74 & 0.72 & 0.69 & 0.76 & 0.74 & 0.73 \\
\hline 2 Penyediaan Makan Minum & 1.06 & 1.06 & 1.07 & 1.09 & 1.06 & 1.07 & 1.07 \\
\hline Informasi dan Komunikasi & 0.90 & 0.95 & 0.99 & 1.03 & 0.88 & 0.87 & 0.86 \\
\hline Jasa Keuangan dan Asuransi & 0.79 & 0.79 & 0.72 & 0.69 & 0.70 & 0.70 & 0.70 \\
\hline 1 Jasa Perantara Keuangan & 1.31 & 1.31 & 1.25 & 1.23 & 1.25 & 1.22 & 1.20 \\
\hline Asuransi dan Dana Pensiun & 0.09 & 0.09 & 0.11 & 0.12 & 0.12 & 0.13 & 0.13 \\
\hline Jasa Keuangan Lainnya & 1.17 & 1.24 & 1.36 & 1.45 & 1.44 & 1.52 & 1.57 \\
\hline 4 Jasa Penunjang Keuangan & 0.002 & 0.002 & 0.002 & 0.002 & 0.002 & 0.002 & 0.002 \\
\hline Real Estate & 0.59 & 0.62 & 0.63 & 0.64 & 0.60 & 0.62 & 0.63 \\
\hline $\begin{array}{l}\text { Jasa Perusahaan } \\
\text { Administrasi Pemerintahan, Pertahanan dan Jaminan }\end{array}$ & 0.20 & 0.20 & 0.20 & 0.21 & 0.21 & 0.21 & 0.21 \\
\hline Sosial Wajib & 0.84 & 0.79 & 0.75 & 0.74 & 0.80 & 0.80 & 0.79 \\
\hline Jasa Pendidikan & 0.89 & 0.99 & 1.05 & 1.06 & 1.16 & 1.15 & 1.19 \\
\hline Jasa Kesehatan dan Kegiatan Sosial & 0.68 & 0.70 & 0.72 & 0.72 & 0.73 & 0.72 & 0.75 \\
\hline Jasa lainnya & 1.06 & 1.05 & 1.02 & 1.03 & 0.995 & 0.95 & 0.95 \\
\hline
\end{tabular}

Sumber: BPS Provinsi Jawa Tengah, 2011-2017

\section{KESIMPULAN}

Dari penelitian yang dilakukan dapat diambil kesimpulan bahwa untuk mengembangkan sektor-sektor non-unggulan tidak mungkin hanya mengandalkan dampak yang diberikan oleh sektor unggulan karena dua alasan: (1) terdapat dua sektor yang sebelumnya pernah menjadi sektor unggulan kemudian turun status menjadi sektor non-unggulan di mana hal ini menunjuk- kan bahwa sulit mengandalkan sektor unggulan menjadi lokomotif bagi sektor non-unggulan lain sementara sektor itu sendiri tidak bisa mempertahankan statusnya sebagai sektor unggulan; (2) terdapat delapan sektor yang tidak pernah menjadi sektor unggulan dan hanya satu sektor yang akhirnya bisa menjadi sektor unggulan. Hal ini menujukkan bahwa sektor unggulan tidak banyak memberikan pengaruh terhadap perkembangan sektor lain. Sehingga, pemberdayaan 
UMKM yang masuk dalam kategori nonunggulan perlu dilakukan dalam rangka meningkatkan perekonomian daerah yang tidak hanya bertumpu pada sektor unggulan.

Beberapa sektor UMKM non-unggulan yang disarankan untuk dikembangkan adalah sub subsektor Industri Kulit, Barang dari Kulit dan Alas Kaki; Industri Karet, Barang dari Karet dan Plastik; Industri Logam Dasar; dan Industri Furnitur untuk mendukung RPJMD Provinsi Jawa Tengah. Selain itu UMKM di subsektor Asuransi dan UMKM di sektor real estate perlu juga mendapatkan dukungan dari Pemerintah Daerah Jawa Tengah.

Selama ini saran penelitian diberikan oleh para peneliti terdahulu biasanya menitikberatkan peran sektor unggulan dalam pengembangan ekonomi daerah karena dianggap mampu menjadi lokomotif pembangunan bagi sektorsektor non-unggulan dan pemerintah daerah diminta untuk membantu sektor unggulan. Saran semacam ini tidaklah sepenuhnya benar. Penelitian ini secara sederhana menunjukkan bahwa sektor unggulan hanya tidak mendorong semua sektor non-unggulan menjadi lebih baik lagi. Selain itu, saran agar pemerintah daerah memfokuskan diri pada pengembangan sektor unggulan adalah salah karena sektor unggulan dinilai sudah dapat berkembang dengan sendirinya dan tidak memerlukan banyak bantuan dari pemerintah daerah. Sebaliknya, Pemerintah Daerah Jawa Tengah perlu mengambil peran yang lebih besar dalam pengembangan UMKM pada sektor-sektor nonunggulan yang seringkali tidak diperhatikan dalam proses peningkatan perekonomian daerah.

\section{DAFTAR PUSTAKA}

Ariyanto, D.C. 2013. Analisis Daya Saing Sektor Unggulan Dalam Struktur Perekonomian Provinsi Jawa Tengah Tahun 2010, Skripsi, Semarang: UNDIP.

Badan Pusat Statistik 2018. PDB Indonesia dalam Angka 2010-2017. Diambil dari: www.bps.go.id, diakses pada 13 Februari 2018.

Badan Pusat Statistik. 2018. PDB Indonesia dalam Angka 2010-2013. Diambil dari: www.bps.go.id di akses pada 12 Februari 2018.

Bank Indonesia 2017. Data Perkembangan Baki Debet Kredit Usaha Mikro, Kecil, dan Usaha Menengah (UMKM). Semarang.

Cahyani, A.D. 2016. Kinerja Ekonomi Kecamatan Untuk Strategi Pembangunan Ekonomi di Kabupaten Wonogiri Tahun 2009-2013, Skripsi, Yokyakarta: Universitas Gadjah Mada.

Dinas Koperasi dan UKM Jawa Tengah 2017. Time Series Data UMKM Binaan Provinsi Jawa Tengah. Semarang

Mawardi, I. 1997. Daya Saing Indonesia Timur Indonesia dan Pengembangan Ekonomi Terpadu. Lembaga Penelitian, Pendidikan dan Penerangan Ekonomi dan Sosial. Jakarta.

Rachbini, D.J. 2001. Pembangunan Ekonomi dan Sumber Daya Manusia. Gramedia Widiasarana Indonesia: Jakarta.

Rencana Pembangunan Jangka Menengah Daerah (RPJMD) Provinsi Jawa Tengah Tahun 2013-2018

Ryantika, I.B.A., dan Utama, M.S. 2017. Penentuan prioritas pembangunan melalui analisis sektor-sektor potensial di Kabupaten Gianyar. E-Jurnal Ekonomi Pembangunan Universitas Udayana, 6(7), pp. 1157-1394.

Sutrisno, A. 2012. Analisis Ketimpangan Pendapatan Dan Pengembangan Sektor Unggulan di Kabupaten Dalam Kawasan Barlingmascakeb Tahun 2007-2010. Economic Development Analysis Journal, 1(2), pp. $42-49$.

Suyatno, 2000. Analisa Economic Base terhadap Pertumbuhan Ekonomi Daerah Tingkat II Wonogiri: Menghadapi Implementasi UU No. 22/1999 dan UU No. 5/1999. Jurnal Ekonomi Pembangunan, 1(2), pp. 144-159. 